Article

\title{
From Contrary to Complementary Models: Central Places and Gateways in the South-Eastern Provence (Arles and Marseille)
}

\author{
Gregor Utz \\ Institut für Klassische Archäologie, Universität Regensburg, Universitätsstraße 31, D-93053 Regensburg, \\ Germany; gregor.utz@gmx.de
}

Received: 30 June 2018; Accepted: 10 August 2018; Published: 13 August 2018

\begin{abstract}
This paper applies the concepts of gateways and centrality, formerly opposing approaches to spatial planning, by now a powerful merged tool for archaeologists, to understand the dynamics of the evolution of cities and settlements in a long-term perspective. The samples are the two main port cities in South-Eastern Provence (France), Marseille and Arles. By means of several archaeological markers it will be shown how natural landscapes and political control influenced the fate of the economic development of both cities in Greco-Roman times. Therefore, this study focuses on the aspects of trade and administration encompassing the functionality of the ports as trans-shipment centers, the impact of political interference as well as the supply and exchange of long distance and local/regional products. Within this research framework, Marseille emerged as a static gateway for its service area with a distinct perspective on Mediterranean trade. Arles, however, was the main gateway for the whole Rhône corridor in Roman times due to its strategic location in an area characterized by a variety of landscapes and the promotion of politics as a port of the annona. The data presented here aim to reject the frequently used narrative of an ongoing competition between Arles and Marseille in favor of a more nuanced picture of economic interactions and overlapping trading networks.
\end{abstract}

Keywords: South-Eastern Provence; Marseille; Arles; centrality; gateways; ancient port cities; trading mechanisms; political economy

\section{Introduction}

At the beginning of every consideration of spatial planning Walter Christaller's famous model of central places takes up a special position. Although his dissertation "Die zentralen Orte in Süddeutschland" was published as early as 1933 [1], it was not until the English translation of his work in the 1960s [2] that Christaller's concept was adopted and refined within Anglo-Saxon processual archaeology. Due to the ideal and local focus of Christaller's hexagonal configuration of market areas that stimulate the best arrangement for urban settlements, several other models were set up from 1960-1980 which account for diverse landscapes as well as regional and inter-regional relations [3] (pp. 23-25).

One of these is the concept of so-called gateway cities, which was established in 1971 by geographer Andrew Burghardt within the framework of North American colonization, using the example of Winnipeg [4]. Beyond the application in the field of historical geography, the concept has been developed further from an anthropological and archaeological point of view in analyses spanning different geographical areas and time periods [5-7]. In particular, the study of Carol Smith on different modes of distribution in pre- and early market systems [8] created the theoretical framework for further discussion: for the examination of the organization and integration of several 
market centers on a regional scale, Smith uses the criteria of networks, i.e., the commodity flows between markets of the same size; of hierarchy, i.e., the commodity flows between markets of different status of hierarchy; of inclusiveness, i.e., the spatial extent of market interactions; and of political congruence, i.e., the spatial organization of markets relative to political unities and boundaries [8] (pp. 314-316), [9] (pp. 83-87). The application of these aspects leads Smith to six ideal systems of market exchange, of which the four main types should be mentioned here: the network system, the solar central-place system, the dendritic central-place system, and the interlocking central-place system.

Contemporary tendencies in using both concepts-that of central places and of gateway cities - in historical and archaeological research are characterized by two main drifts: one revolves around network theory, the other reflects Christaller's centrality in a general way as a "relative concentration of interaction" [10] (p. 219). As a consequence, the gateway concept is no more an alternative draft to the central place theory, but integrates well into the dynamic understanding of centrality. Moreover, this abstraction of centrality permits both concepts to be merged into a powerful tool for archaeologists and archaeological markers that were compiled for the more familiar central place model to be identified.

This paper aims to focus on the aspects of trade and administration encompassing the functionality of the port as a trans-shipment center with its infrastructure and buildings, the impact of political interference, as well as the supply and exchange of long distance and local/regional products. By looking at two port cities in South-Eastern Provence, Marseille and Arles, and their contributory areas throughout time, the dynamic evolution of these cities as competing and complementary places can be tracked and defined more precisely with the help of centrality and the gateway model. The application of both concepts to explain the fates of two nearby cities in the Greco-Roman world is rarely pursued: historian Simon Loseby does frequently cite the term 'gateway city' in his paper on Marseille in Late Antiquity, but the inclusion of the presented thoughts in the theoretical concept was not carried out [11]. It is the promising analysis of the central functions of Pergamon and Ephesos by Daniel Knitter that points to the potential of such studies [12] (pp. 29-47), [13].

This paper tries to contribute to several questions concerning the interdependency of the economic development of Marseille and Arles: was it competition along the trading routes that led to a loss of locational advantage for one or the other city? What role did the political interventions for the development of economy and power play (confiscation, promotion, laws)? To what extent was this predetermined by natural resources and conditions (accessibility, fertility) or influenced by geological changes (sedimentation, floods)? The answers will lead to a significant contribution to the discussion of the functions of both ports rejecting the narrative of an ongoing competition in favor of a more nuanced picture of interactions between Marseille and Arles in Roman times.

\section{The Concept of Gateway Cities}

According to Burghardt [4], a typical gateway city is located on a narrow strip of land along natural corridors of communication or on critical passages between areas of high soil productivity, high demand for scarce resources and economic shear lines, where cost factors change. As you have to pass this city in order to enter the hinterland or to leave that area, the gateway city is in charge of the control and exchange of the flows of products, persons and ideas between the outside worlds and the target area. Thus, the gateway city is placed on the outer limits of its service area, which is elongated and forms a dendritic market network with settlements in the hinterland. If one translates this into a scheme and adapt it for port cities on or near the coast, we get the following picture (Figure 1): the gateway city is linked to interconnected Mediterranean markets by long-distance trade routes. Since it provides the only possibility for shipped goods to be transferred to the urban markets or the associated service area, the port district of the city constitutes a core area for breaking down the bulk supplies from ships to barges into carts or storage spaces. In a further step, the goods are transported to the settlements in the hinterland and get incorporated into the local and regional network of the service area. Thus, one important characteristic of gateway cities concerns their location 
in an area with a high significance in terms of transportation, in order to satisfy the demand for resources by trading and to minimize transport costs. Because of the overseas trade, the city itself is the reference for all other cities or settlements in the service area and dictates market prices. The local trading networks accept this hierarchical dependency: Their actors take care of the supply chain and absorb, thereby, a large part of the cost for goods-processing. The gateway communities maintain the trading infrastructure (i.e., routes, harbor basin) and provide a secure exchange. The importance of a consideration of the interaction between material flows and the city as a "site, place or scalar configuration in which material processes ... are embedded" [14] (p. 75) has been stressed by Markus Hesse from a present-day perspective, especially in regard to modern seaports [14] (pp. 83-87).

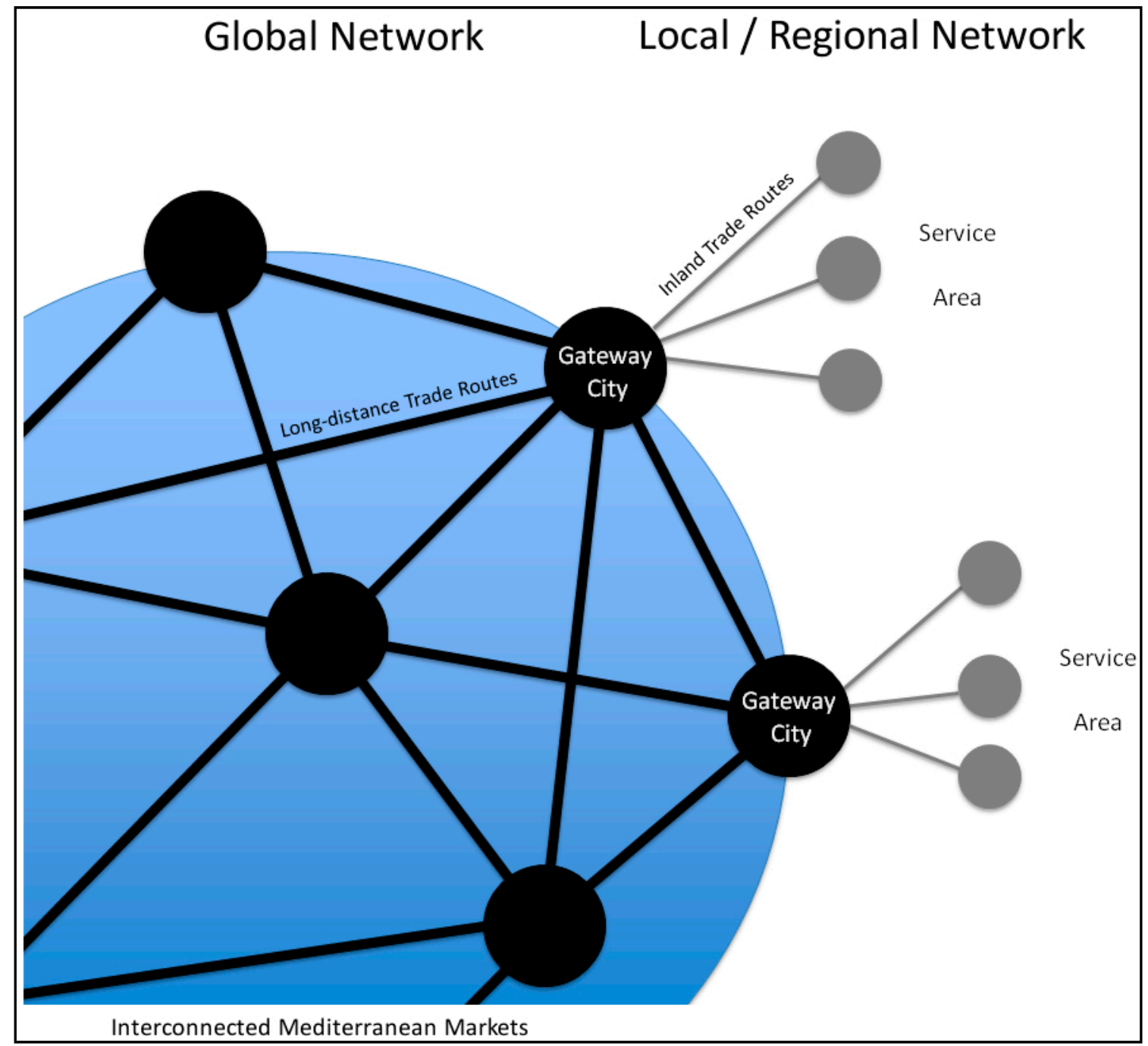

Figure 1. Scheme of port cities acting as gateways between two different market networks.

One of the advantages of the gateway model concerns its dynamic of retracing the evolution of the port cities [4] (pp. 272-273): The first step is always visible in a boom in building projects and infrastructure, during the growth of trade and population. If the service area of the gateway city is large and the cultivated land fertile enough, it is possible that new central places can emerge within this area. Subsequently, the former gateway assimilates to a central place, but with a higher hierarchical status than the other cities due to its favorable position for transport and trade. If, however, the service area is small, the gateway city keeps its function and a static situation exists. 
In the case of decreasing power of a gateway city a few possible reactions on behalf of the city exist [5] (p. 42): on the one hand, it can restrict its influence to the remaining sector, which results in an economic downturn. On the other hand, it can turn its focus onto new geographical areas that are unaffected by the emerging central place. Alternatively, the city itself increases its own competitiveness by the formation of new socio-political authorities: They can promote the gateway city; military actions can enlarge the service area or eliminate the competitor; new classes like specialized traders or markets can move the boundaries; and newly established trading routes can increase the locational advantage of the gateway. Thus, the influence of political decisions on the fate of these cities is immense.

\section{Arles and Marseille}

The two cities of Marseille and Arles in South-Eastern Provence offer a worthwhile case study. Located within a range of about $90 \mathrm{~km}$ of each other the development of both cities was closely connected and dynamic throughout the whole Greco-Roman era (Figure 2).

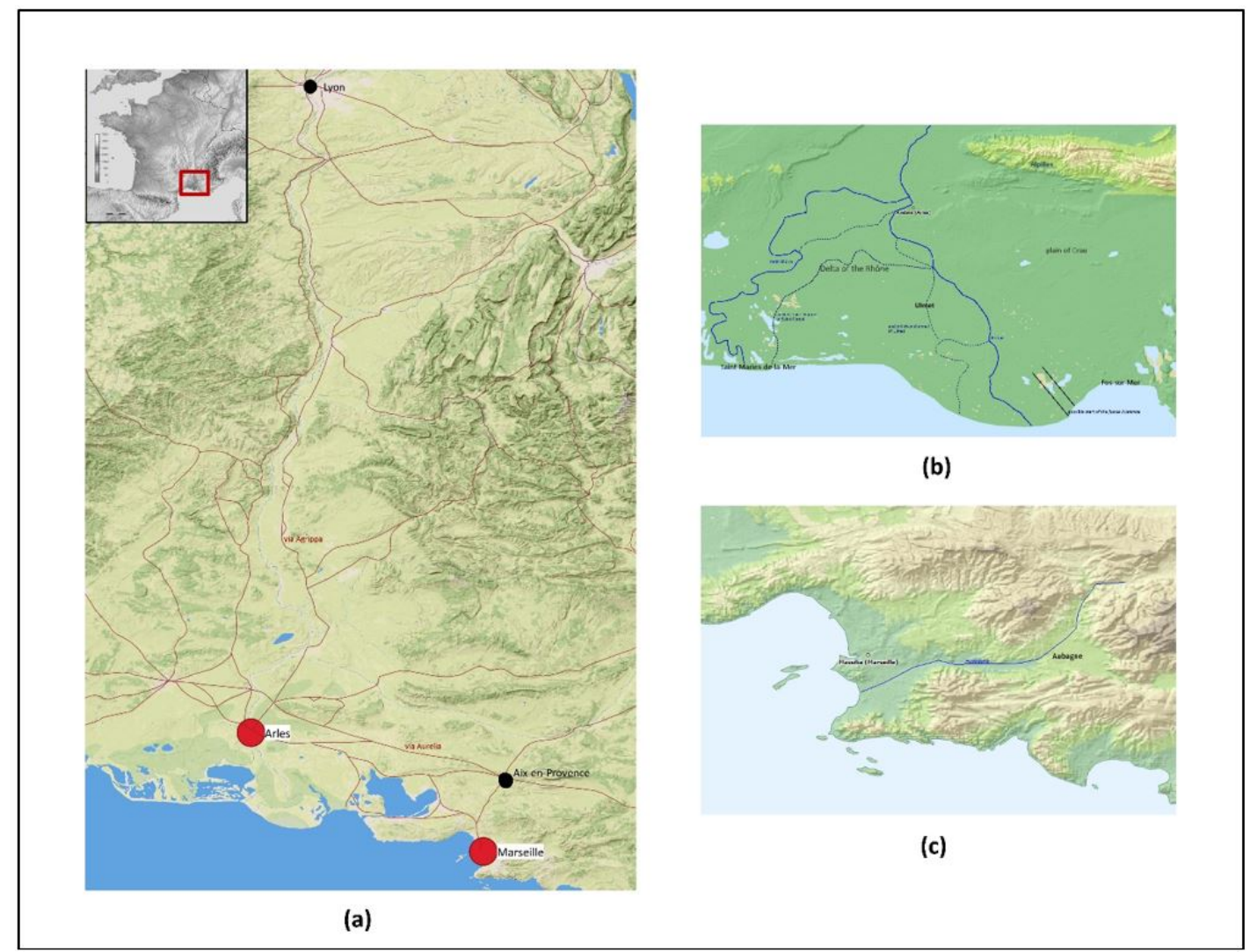

Figure 2. (a) Map of the Rhône corridor showing the main sites, streets and geological features mentioned in the text [15]. (b) Detail of the landscape around Arles showing the main sites, modern and ancient river courses and the assumed starting point of the fossae Marianae. (c) Detail of the landscape of Marseille showing the main site, the approximate course of the river Huveaune and the geological features. Base map (C) Ancient World Mapping Center, http://awmc.unc.edu/wordpress/map-files/.

\subsection{The Natural Environment and Transport Geography}

When the Phocaeans founded Massalia as an apoikia in the natural bay of modern Marseille around $600 \mathrm{BC}$, the main arguments for the location of the colony comprised the existence of a safe and secure harbor basin — protected from the sea currents and the Mistral—and the possibility to fortify the surrounding city hills (Figure 2c). Until the second century BC, it was the maritime perspective that was the most important in order to extend the Phocaean trade network on a micro- (Southern 
Provence), meso- (Iberia, Italy) and macro-level (Asia Minor), with Massalia as a point of departure [16] (pp. 143-169). Thus, the immediate environment was limited to few kilometers and was completely cut off from the inland by the massifs of Estaque and Étoile in the north, Garlaban in the east, and the foothills of the Calanques in the south. Solely the navigable river Huveaune provided access to the small and likewise enclosed plain of Aubagne in the east of Marseille. Therefore, the agricultural use of the hinterland with vine and olive trees was possible, aimed, however, only at the self-sufficiency of the settlements and Marseille itself, and not at a mass export. Pliny the Elder praised the characteristic taste of the wines of Marseille and reported on awareness of it in the Roman world (Plinius, naturalis historia 14.8.38); therefore the export of special quality commodities in low numbers has to be assumed. Clay and rocks for building activities were easily accessible $[17,18]$. To enter the Rhône plain, one had to cross the hilly passage north of the city, which did not become comfortable until the link to the via Aurelia had been established to reach Aix-en-Provence (Aqua Sextiae) and Arles (Arelate).

Arles on the other side acted since the beginning as a trading post between Celtic-Ligurian tribes in the Gallic inland and Phocaean colonies at the seaside (Figure 2b). The city itself consisted of an autochthonous district and the newly founded emporium called Theline (c. 540/30 BC), which has to be on the later urban area of Arles, but remains archaeologically unlocated. At $35 \mathrm{~km}$ distance to the mouth of the Rhône, this urban conglomeration built on limestone rock was the first safe location to cross the river, so that its position resembled one of a coastal strip. It formed a junction between the wide and high-yielding plains with adjacent valleys on the east and west of the city and the stream of the Rhône, which connected the inland with the Mediterranean. The variety of natural environments encompassed in the north agricultural land, especially for grain cultivation, in the north-east the limestone massif of the Alpilles as a source for water and building materials, in the east the unfertile plain of Crau, that was ideal for sheep herding, and finally in the south the alluvial soil of the delta [19]. In terms of the overland communication axes, in and near Arles several of the main Roman long-distance roads crossed the area and made the city a hub for east-west (via Aurelia) and south-north (via Agrippa) traffic.

\subsection{Natural and Political Factors}

After having experienced a significant boom in growth and wealth-for Arles instantly after its foundation, for Marseille after the Punic wars, when its area of influence expanded to a wider hinterland, parts of modern Liguria and others-both cities and their further development were influenced mainly by natural and political factors.

For Marseille, a major issue consisted in the siltation and maintenance of the harbor basin (Figure 3). Direct witnesses of that fact are three wrecks of the first and second century AD, being found in the layers of the port sediments at the place Jules-Verne, whose form point to dredging ships. Furthermore, the archaeological excavations revealed traces of at least three larger dredging activities in the basin between Augustan times and the fourth century AD [20] (p. 48). The alterations of the access to the waterfront could explain why there was such a heterogenic conception: sections of the quay were built with monumental stone blocks (quai de la Samaritaine), and others were shored up by wooden planks and stakes and had piers projecting into the basin (place Jules-Verne) [20]; elsewhere, an open gravel area was created (place Général-de-Gaulle) [21] and the so-called corne $d u$ port, the artificially cut inner basin of la Bourse, was narrowed several times [22]. If we look at warehouses and magazines, a shift from many archaeological structures for storing bulk wine in dolia in the first and early second century AD to few warehouses for storing wine in amphoras in the late second to fourth century AD can be observed around the port basin. This fact is a common feature in many Roman ports of southern France [20]. 


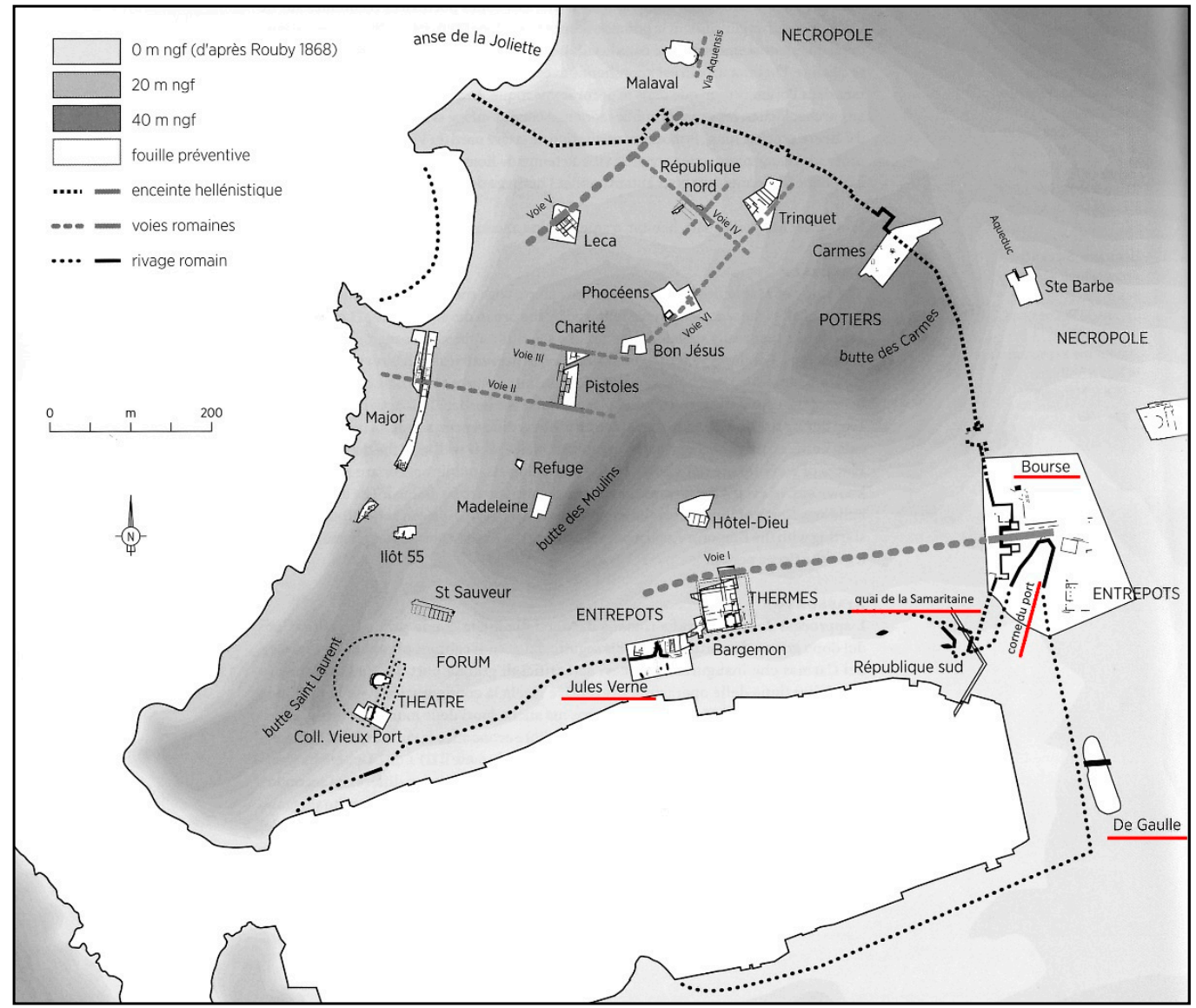

Figure 3. Plan of Marseille with the most important sites mentioned in the text (after B. Sillano [23] (Figure 1)).

The urban development of Arles was determined by frequent and strong inundations of the Rhône like the one in $175 \mathrm{BC}$, which destroyed large parts of the city (Figure 4). Furthermore, these forces altered the course and the number of arms of the river in its delta-differing mentions in the literal records from two to seven arms reflect this unstable dynamic [24]. In the city of Arles, modern urbanism and the force of the Rhône have destroyed most evidence of the ancient fluvial port. On the right bank of the river (modern Trinquetaille) several fragmented structures let us think of a homogenously planned port district. A promising archaeological record is made in the area of the gare maritime, where parallel walls on a large scale might represent a great warehouse [25]. Some substantial rows of arches that came to light recently on the left bank at the place J.-B. Massillon can be interpreted as some sort of protection against the flood, a weakening mechanic against the stream [26]. Large rows of amphoras that are stacked vertically in the ground at several places on the right bank of the river can be interpreted as an attempt to secure the danger zone. In addition, two large assemblages (gisements) of building material, ceramics, statue fragments, pebbles, etc. that accumulate in the river itself near the right bank might be the remains of the backfill of the original quayside, being washed into the river during one of its destructive incidences in the fifth or sixth century AD. 


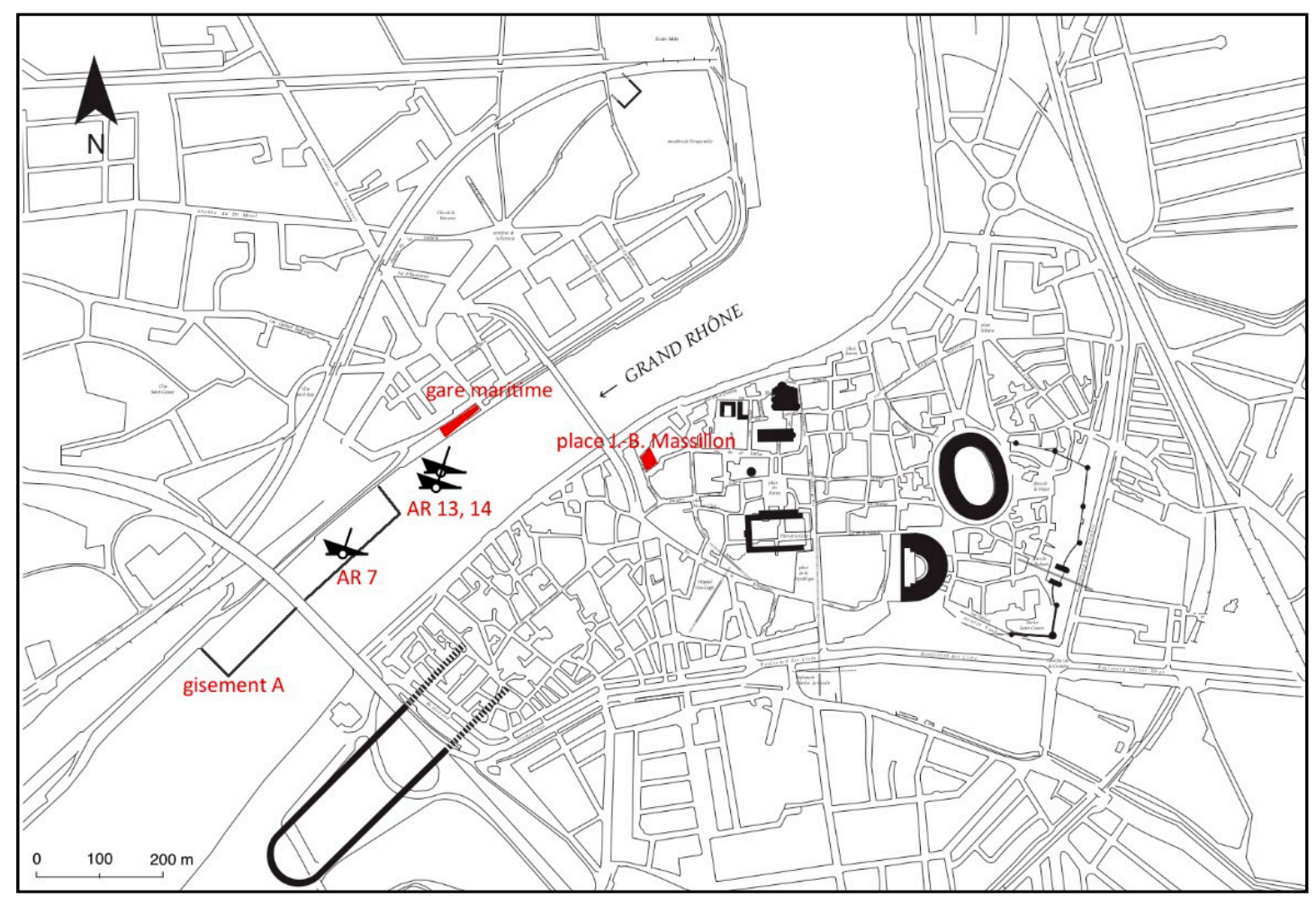

Figure 4. Plan of Arles with the most important sites mentioned in the text (after M. Heijmans [27] (pl. I)).

Besides the hydrological difficulties, two political decisions shaped the future development of both cities. Firstly, the consul Marius ordered to construct a navigable canal in 103/02 BC, the fossae Marianae, which connected the fluvial port of Arles with the bay of Fos [28]; its course is only partly attested archaeologically (Figure 2b: see the parallel lines). Thus the troublesome ingress of large ships into the mouth of the Rhône became obsolete. The fossae formed a quick and easy way to provide military and food supply and strengthened the link between Rome and Arles, leaving Marseille aside. It seems, however, that this new canal was out of use as early as in the first century AD. Therefore, another system was established, also advantageously for Arles: several small trans-shipment-centers like Saintes-Maries-de-la-Mer, Fos-sur-Mer and Ulmet were installed on the coast south of Arles to transfer the trading goods from deep-sea vessels to specialized fluvio-maritime ships [29]. Although these activities and the necessary workforce caused additional costs, one gained an optimized cycle of ship traffic in the Rhône delta and control over the number of ships, duration and length of the trip.

As a second political factor, the consequences of the civil war between Caesar and Pompey (49-45 BC) must be cited. After having chosen the wrong side, Marseille lost-besides the treasury, weapons and ships-wide parts of its former territory along the Ligurian coast, but also in its immediate environment to Arles and Lyon. The colonial territory of Arles consisted now of mosaics of land strips, but as well gained additional resources [30].

Its geographical position, a large hinterland and the importance for supplying the whole province as well as adjacent provinces made Arles the nodal point of economic and political interests: on the one hand the city was partly destroyed and besieged in the third and especially in the fifth century AD by Germanic tribes and Roman usurpers; on the other hand it was a destination for the annona-ships carrying grain and olive oil for supplying cities and military in a contractual framework of the Roman state. Evidence of the presence of this promotion in Arles by the Roman state is presented through several inscriptions mentioning corpora like the lenuncularii, the utricularii and the navicularii that were incorporated in state services [31]. More precisely, a bronze plate found near Beirut in modern Lebanon 
describes a dispute between the navicularii of Arles and some officials of the grain transport, settled by the praefectus annonae [29] (p. 36).

Marseille developed into an intellectual center and was characterized by an impressive Christian topography in late antiquity. Nonetheless, the city maintained its economic importance which is shown by some wooden toll plates from the port district, two of which are marked with (Quadragesima) Gall(iarum) st(atio) Mass(iliensis), that is the office which was responsible for raising the $2.5 \%$ tax on imported and exported products [32].

\subsection{The Role of Supply}

To get a quantitative insight into the imported products of both cities, quantified assemblages belonging to more or less reliable circumstances found in the immediate port area permit some interesting observations. For Arles, the analyzed data covers the time span from the second to the fifth century AD, including material from the excavations at the place J.-B. Massillon [33] (pp. 76-96, Tables 1-3) and the gare maritime [34] (pp. 191-192), and from the sondages around the wrecks Arles-Rhône 7 [35] (pp. 41-42, Figures 8,9), 13 [36] (pp. 128-129, Tables 1,2; p. 132, Tables 3,4) and 14 [37] (p. 134, Figure 18). The findings from Marseille derive from several sondages in the area of la Bourse, i.e., the area around the north-eastern corner of the port basin: sondages DY09 [38] (p. 381, Table 5); 6/7 [38] (pp. 385-390, Tables 11-25), [39] (p. 171, Figure 6); 10 [38] (pp. 391-395, Tables 26-46); 11/12 [38] (pp. 396-400, Tables 47-55); aires 1 and 2 [40] (pp. 302-346), [41] (pp. 302-304, Tables 1-6); wreck [38] (pp. 383-385, Tables 8-10). Here, however, the data covers only the first half of the third century and the fifth century AD. The comparability of the assemblages is ensured by the proximity to the port area, the similar nature of the archaeological record-mainly washed up and accumulated sediment layers - and by the homogenously quantified ceramics. All assemblages have been quantified by the counting of all shards except one from Arles, of which only the so-called NTI (nombre typologique d'individus) was published. Due to the nature of research, only fine and coarse wares as well as amphoras can be considered.

For Arles in the second to fifth century AD, the supply of plain and coarse ware was dominated by regional Gallic production from the central Rhône valley transported via the river as a fast trade route (Figure 5; Appendix A, Table A1): the terra sigillata luisante was manufactured in the valleys of the Savoy, the workshops of the terra sigillata clara B were located in the area between Lyon and Vienne, and those of the céramique métallescente in an area between Trier and Lezoux. Wares from Southern Provence were significantly less present, including the DSP (dérivées des sigillées paléochrétiennes) and the céramique à pâte claire produced around Marseille and the so-called south-gallic terra sigillata. Across the Mediterranean, ARS (African Red Slip Wares), especially, were transported to Arles, but some cooking wares from modern Tunisia, too. Imports on a smaller scale from Spain, Italy and the Eastern Mediterranean complement this picture. The bulk of the amphoras were imported from North Africa with a growing percentage up to $70 \%$ from the third century AD on, above all the classic types Africana 1 and 2, but also the type Leptiminus II. The workshops of southern Iberia made up $10-20 \%$ of all amphoras, and together with those of southern Italy $(10 \%$ in the fourth century $\mathrm{AD})$ and Gallia itself they represent reliable and constant trading connections during Late Antiquity. The data for the amphora types from the eastern Mediterranean is the most puzzling: Their values fluctuate in the contemporaneous urban and port assemblages from 3-44\%. One possible explanation of the existence of such a bandwidth might be that the smallish eastern containers were loaded onto carts in Marseille or onto barges in one of the trans-shipment points at the coast; then the amphoras would have been transported to the main hub, Arles, where some of them were distributed on the urban market, and some were stored in the magazines for further distribution into the hinterland. 


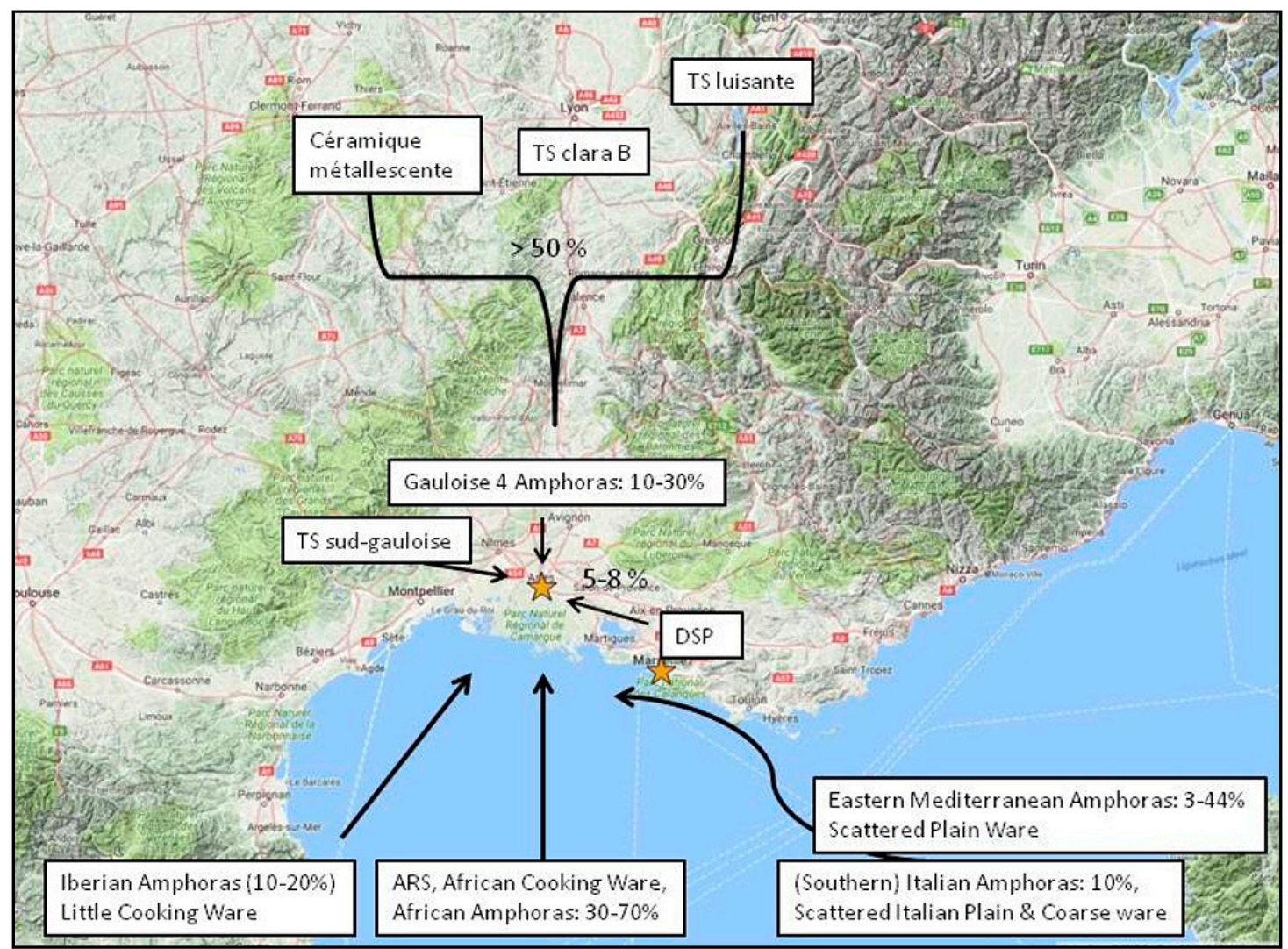

Figure 5. Map showing the intervals of percentages of fine wares, coarse wares and amphoras from the port assemblages of Arles, second to fifth century AD (after Appendix A, Table A1). Base map (C) Google Maps.

The data from the port area of Marseille show clear differences (Figure 6; Appendix A, Table A2): already for the first half of the third century AD the shards of the plain and coarse wares show a higher frequency of production from southern Gaul than from the central Rhône valley. This culminates in the fifth century AD, when the assemblages from Marseille consist of $72-84 \%$ of DSP-wares. Even though no atelier of these fine ceramics has been identified yet, the clay analyses point straight to the clay sources in the Aubagne plain in the immediate hinterland of Marseille [42] (pp. 261-262). The same observations are valid for the céramique à pâte claire or grise. It is obvious that those pots from the central Rhône valley that make up the majority in Arles are only scarcely represented in Marseille. Besides the steady supply of ARS and African cooking wares there are some minor quantities of Italian fine and coarse wares as well as table wares from the eastern Mediterranean. In regard to the amphoras, one recognizes a shift from 50\% Gallic containers around $200 \mathrm{AD}$ to the absolute lack of local production in the fifth century AD. This development was in favor of amphoras from the eastern Mediterranean that made up to more than one third of all amphoras. Together with the disappearance of Hispanic containers, the transition of the supply of middle Italian amphoras to southern Italy and the strong partnership with North African traders, it seems that the supply of Marseille with foodstuff transported in amphoras was much more linked to the external economical trends in trade during late antiquity than Arles [11] (pp. 170-174). 


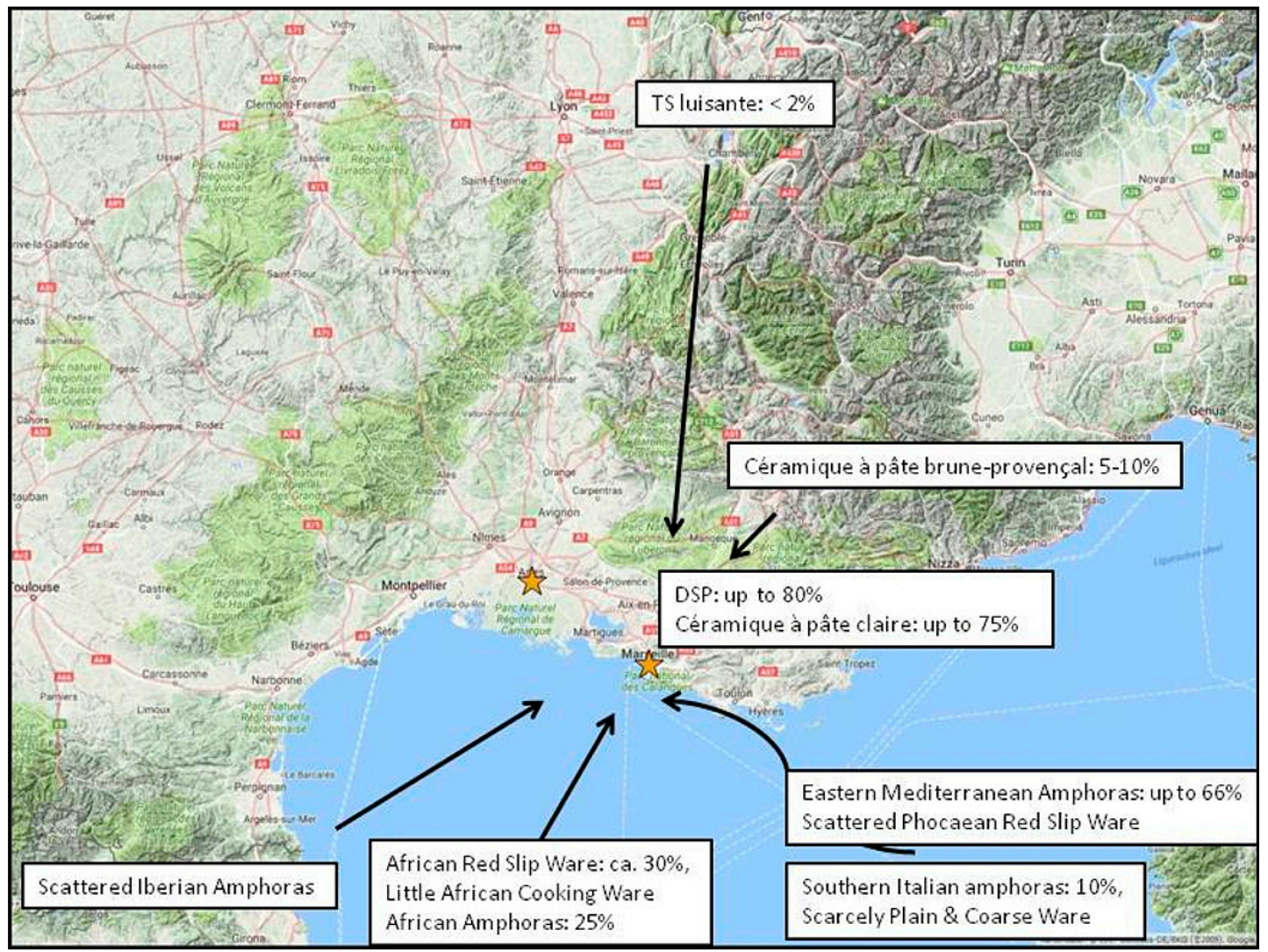

Figure 6. Map showing the intervals of percentages of fine wares, coarse wares and amphoras from the port assemblages of Marseille in the fifth century AD (after Appendix A, Table A2). Base map (C) Google Maps.

\section{Gateways and Centrality}

If we return to the concept of gateway cities and the issue of centrality, how can these theoretical frameworks help us interpret and explain the presented data? Marseille and Arles had been gateways or places with a high centrality: on the one hand, with a geographically very restricted service area; on the other, with an enormous potential regarding the hinterland. The river Rhône and in extension the Saône made the whole corridor from Arles in the south up to Lyon and further north one economic unit, in which other cities and settlements could emerge over time at a certain distance, for example Lugdunum (Lyon). Both cities were located in places with a high geographical significance related to the circulation of goods and persons. This is why they had major power over the control and distribution of trading goods, apparent through the existence of toll stations (stationes) [43] (pp. 24-31, 44-46). The port installations and trans-shipped products help understand that the role of long-distance trade was immense and contributed to the hierarchical status of the cities as an essential supply node for the tributary hinterland. The city officials and associations took care of reliable trade routes, the sufficient depth of the port basin, adequate mooring places and a fast and comfortable transport of the products into magazines or straight to the local market. Even if Marseille and Arles suffered different fates in late antiquity-loss of political territory for Arles, Marseille being a place of retreat for the Roman and Christian aristocracy-the long-distance trade seems to have been unaffected.

Massalia evolved from a Phocaean colony by means of increasing territorial control to a place with high centrality, especially for trade. For its small service area, it remained one static gateway for a long time. This explains why the supply of the late antique Massilia with pots produced in the city itself or the immediate hinterland could compete with the ARS wares that flooded the markets of the western Mediterranean port cities almost everywhere else. Furthermore, these productions saturated 
the city market, so that in consequence there was no place left for other Gallic wares. For foodstuff, however, one was mainly dependent on imports and long-distance contacts with other provinces at all times. With the politically motivated rise of Arles, Marseille became increasingly unimportant as a gateway, but obtained its hierarchical status due to the strategic position of its port.

In contrast, Arles was planned from the outset as a gateway city, and after the initial boom it benefited from its unique geographical position and, in consequence, from the economic potential of the city and its wide service area. This caused politics to promote the status by a new system of economic infrastructure, the fossae Marianae and, consecutively, the trans-shipment centers on the coast-despite the imminent danger of flooding that put an end to urban development in the sixth century AD. Arles had control over various resources and was an annona port with special rights and a specialized workforce for the port activities. It seems that what we have here is a politically motivated strategy of maximization which placed the importance of the city on an economic foundation. In this sense, Arles is a good example showing how closely the status of a dynamic gateway is linked to the model of political economy [44]. This supra-regional level of centrality explains the supply of Arles with products manufactured in the distant central Rhône valley ignoring those from Marseille and the nearby environment. Due to the river, no other gateway or proper river ports could become established inside the service area of Arles along the Rhône as a competitor: The river constituted a fast trade route, and kept transport costs low, and the distance between cities high. Despite the focus of Arles on the Gallic inland, the city constantly received foodstuff as imports from production centers across the whole Mediterranean.

If we take a look into academic literature, one narrative defines the relationship of Marseille and Arles in Roman times: the events of the civil war as a drastic turning point for the future urban development and relation of both port cities. Whereas Raoul Busquet and Régine Pernoud describe the economical role of Marseille in imperial times as commerce in slow-motion (commerce au ralenti) in comparison to the status in the pre-Roman era [45] (pp. 87-95), S. Loseby stresses the ongoing competition between the two cities after the punishment of Marseille resulting in the loss of its status as the main gateway in the area. Moreover the author uses this narrative of Marseille as a backwater in order to focus on its reappearance as focal port for trading and passengers to the disadvantage of Arles at the end of the sixth century AD [11] (pp. 179-183). If one considers all the evidence presented above, it seems that the economic interactions between Arles and Marseille need to be described in a more nuanced manner. Arles certainly was the main gateway for the Rhône corridor during Roman times-the role of Marseille, however, was not a minor and competitive one: the city of Marseille was a complementary part of the supra-regional trade network of Arles; but together with its service area it was also an independent consumer city that imported products from the Mediterranean markets and produced wares to meet the demand of the city itself. This idea of interlocked economic practices with an internal and external range gets support from the research of Jane Jacobs and more recently Peter Taylor about urban development, who stress the importance of cooperating commercial agents in cities with complementary functions $[46,47]$. Some additional archaeological observations might make this clearer: in the Roman villa of Goiffieux at Saint-Laurent-d'Agny, which is located some $25 \mathrm{~km}$ to the south-east of Lyon, a fragment of an amphora with a titulus pictus was found [48]. The shard belonged to a type produced in the workshops of les Carmes in Marseille during the first century AD and on it there were remains of raisins cultivated in the Aubagne plain in the territory of Marseille. The painted inscription gives us an interesting insight into the trade route of this amphora: the known trader, Marcus Licinius Rufinus, who had bottled and sent off the wine container from Marseille, conducted business with a certain Staius Regillus as the recipient, but the amphora was registered in and transported via the port of Arles. Therefore, the incorporation of Marseille in the supply network of Arles is epigraphically attested. Another clue stems from the represented African amphora types in the assemblages of Marseille and Arles: in the first half of the third century AD, we find in Arles a variety of North African containers with the Africana 1, 2 and the Leptiminus II as the main types. The latter is absent in Marseille, but the city imported a significant amount of Dressel 30-amphoras, 
presumably from Mauretania Caesariensis. Even if the question of the content of an amphora type is not an easy one [49] (pp. 463-475), we can assume that they contained different products (garum, wine, oil); thus, Marseille's imports added to the supply of the whole region. Together with the high percentages of amphora imports from the eastern Mediterranean in Marseille and the constant supply of Arles with Iberian and Gallic containers, it seems that there was a complex interaction of the trading mechanisms of both port cities. One explanation for these partly overlapping, partly differing, trading connections might be the fact that both cities had a distinct focus: Arles was orientated on inland trade, as an annona-port it was also supplied with products of the Mediterranean; Marseille, instead, had its main focus on sea trade and acted more as a hub for traders performing cabotage and tramping. The ships departed from one of the ports of the Tyrrhenian coast or from other primary or secondary port systems on the Ligurian coast or the Gulf of Lion like Forum Iulii (Fréjus), Antipolis (Antibes), Lattara (Lattes) and Narbo Martius (Narbonne); then, they sailed along the coast and anchored in sea ports like Marseille where products were sold and acquired at the market price [50] (pp. 107-126), [51]. Future research in the named port cities will provide deeper and more precise insights into the distribution systems and interplay of the commodity flows of the whole region. In conclusion, it was the geographical proximity of the two economic systems that led to the interwoven interaction of Marseille and Arles.

\section{Concluding Remarks}

This article tried to demonstrate that the concept of 'gateways' can contribute to the discussion of the development of cities in Greco-Roman times by using archaeological markers that were acquired for use within issues concerning centrality and central place theory. The locational advantage of Arles in the midst of an area adjoined by several cultural landscapes was its decisive difference to Marseille. Thus, it was the political decision of the Roman government to support Arles as a port city that outweighed the environmental danger of the frequent inundations. As a consequence, Marseille lost its predominance and was now one important trans-shipment port of the prevailing Arles gateway. In this regard, Marseille complemented the supply of Arles and the whole Rhône corridor, but was also a static gateway for its own tiny service area, in which tableware was produced on a large scale for the demand of the city and export along the coast. The functioning of Arles as the main gateway was facilitated by the river Rhône which served as a fast, safe and cheap trade connection to the Gallic inland. The complicated and dynamic interaction between both cities cannot be explained altogether by the use of the gateway concept. However, the concept provides a helpful framework to understand that there was no competition between Marseille and Arles on an economic level, but they were part of an integrated system of networks. The dynamic of the Arles gateway integrated the static centrality of Marseille.

Funding: This research received no external funding.

Acknowledgments: This paper has benefited greatly from a research stay at the Centre Camille Jullian during March 2015, where I could look at the available material and discuss several issues with the local researchers. I kindly received the excavations reports of the gare maritime by Philippe Mellinand and of the place Jean-Baptiste Massillon by Delphine Isoardi. Pauline Gohier sent me her master's thesis for the analysis of the ceramics of this excavation. Furthermore, I want to thank Dirk Steuernagel and the reviewers for their useful remarks on this topic as well as the whole audience, especially the discussant John Bintliff, for the helpful comments on this contribution at the XIXth International Congress of Classical Archaeology in Cologne and Bonn (May 2018), where a shortened version of this paper was submitted. Finally I received support for the correction of the English text by Richard Utz.

Conflicts of Interest: The author declares no conflict of interest. 


\section{Appendix A}

Table A1. Percentages and intervals of percentages of fine wares, coarse wares and amphoras (including the main types) from the port assemblages of Arles. Data from [33] (pp. 76-96, Tables 1-3), [34] (pp. 191-192), [35] (pp. 41-42, Figures 8,9), [36] (pp. 128-132, Tables 1-4), [37] (p. 134, Figure 18). Quantified by the counting of all shards: time spans 175-250 AD; 450-500 AD. Quantified by the estimation of the NTI (nombre typologique d'individus): time span of 300-425 AD.

\begin{tabular}{|c|c|c|c|}
\hline Fine Wares & 175-250 AD & 300-425 AD & $450-500 \mathrm{AD}$ \\
\hline terra sigillata clara B & $73 \%$ & $8 \%$ & \\
\hline céramique métallescente & $10 \%$ & & \\
\hline terra sigillata luisante & & $36 \%$ & $57 \%$ \\
\hline terra sigillata sud-gauloise & $5 \%$ & & \\
\hline DSP-Wares & & $8 \%$ & $7 \%$ \\
\hline Other Gallic Wares & & $4 \%$ & \\
\hline African Red Slip Ware & $6 \%$ & $44 \%$ & $33 \%$ \\
\hline Glazed Italian Ware & $3 \%$ & & \\
\hline Eastern Plain Ware & $1 \%$ & & \\
\hline Coarse and Cooking Wares & 175-250 AD & $300-425 \mathrm{AD}$ & $450-500 \mathrm{AD}$ \\
\hline céramique à pâte claire & $19-34 \%$ & $15 \%$ & \\
\hline grise de Vaison & $7-9 \%$ & $8 \%$ & $14 \%$ \\
\hline Other Gallic Wares & $7-12 \%$ & $27 \%$ & $18 \%$ \\
\hline African Cooking Wares & $34-61 \%$ & $47 \%$ & $18 \%$ \\
\hline Italian Cooking Wares & $2 \%$ & $2 \%$ & $11 \%$ \\
\hline Eastern Coarse and Cooking Wares & $4-5 \%$ & $2 \%$ & \\
\hline Amphoras & 175-250 AD & $300-425$ AD & $450-500 \mathrm{AD}$ \\
\hline Gallic (Gauloise 4) & $6-34 \%$ & $20 \%$ & $10 \%$ \\
\hline North African (Africana 1,2,3; Leptiminus II; spatheion 1; Dressel 30) & $29-39 \%$ & $42 \%$ & $70 \%$ \\
\hline Iberian (Almagro 51c, Dressel 23) & $9-20 \%$ & $11 \%$ & $12 \%$ \\
\hline Italian (Middle Roman 1a, Keay 52, Empoli) & $0,5 \%$ & $7 \%$ & $1 \%$ \\
\hline Eastern (Agora F65-66, Célestins 1a min., Late Roman 1) & $10-22 \%$ & $16 \%$ & $4 \%$ \\
\hline
\end{tabular}

Table A2. Percentages and intervals of percentages of fine wares, coarse wares and amphoras (including the main types) from the port assemblages of Marseille. Data from [38] (pp. 381-400, Tables 5-55), [39] (p. 171, Figure 6), [40] (pp. 302-346), [41] (pp. 302-304, Tables 1-6). Quantified by the counting of all shards.

\begin{tabular}{ccc}
\hline Fine Wares & $\mathbf{2 0 0 - 2 5 0 ~ A D ~}$ & 425-525 AD \\
\hline terra sigillata clara B & $24 \%$ & \\
terra sigillata luisante & $5 \%$ & $1-2 \%$ \\
terra sigillata sud-gauloise & $33 \%$ & $72-84 \%$ \\
DSP-Wares & & $10-26 \%$ \\
African Red Slip Ware & $24 \%$ & \\
terra sigillata hispánica & $1 \%$ & $0.5-1 \%$ \\
Italien Thin Walled Wares & $11 \%$ & $\mathbf{4 2 5 - 5 2 5 ~ A D ~}$ \\
Phocaean Red Slip Ware & $\mathbf{2 0 0 - 2 5 0 ~ A D ~}$ & $6-8 \%$ \\
Coarse and Cooking Wares & $20 \%$ & $10-15 \%$ \\
céramique à pâte claire/grise & $5 \%$ & $0.5-2 \%$ \\
brune provençale & $5 \%$ & \\
Other Gallic Wares & $46 \%$ & \\
African Cooking Wares & $9 \%$ & \\
Italian Coarse and Cooking Wares & $5 \%$ & \\
Eastern Coarse and Cooking Wares & & \\
\hline
\end{tabular}


Table A2. Cont.

\begin{tabular}{ccc}
\hline Amphoras & 200-250 AD & 425-525 AD \\
\hline Gallic (Gauloise 4) & $50 \%$ & \\
North African (Africana 1,2,3; spatheion 1; Dressel 30; Keay 35) & $21 \%$ & $19-54 \%$ \\
Iberian (Almagro 51a-b, Dressel 20) & $11 \%$ & $0.5-2 \%$ \\
Italian (Dressel 2-4 ital, Keay 52) & $10 \%$ & $2-10 \%$ \\
Eastern (Late Roman 1,3,4) & $4 \%$ & $12-44 \%$ \\
\hline
\end{tabular}

\section{References}

1. Christaller, W. Die Zentralen Orte in Süddeutschland. Eine Ökonomisch-Geographische Untersuchung über die Gesetzmässigkeit der Verbreitung und Entwicklung der Siedlungen mit städtischen Funktionen; G. Fischer: Jena, Germany, 1933.

2. Christaller, W. Central Places in Southern Germany; Prentice-Hall: Englewood Cliffs, NJ, USA, 1966.

3. Hodges, R. Dark Age Economics. The Origins of Towns and Trade; Duckworth: London, UK, 1982; ISBN 0-7156-1531-9.

4. Burghardt, A.F. A Hypothesis about Gateway Cities. Ann. Assoc. Am. Geogr. 1971, 61, 269-285. [CrossRef]

5. Hirth, K.G. Interregional Trade and the Formation of Prehistoric Gateway Communities. Am. Antiq. 1978, 43, 35-45. [CrossRef]

6. Messerschmidt, D.A. Gateway-Hinter Relations in Changing Nepal. Contrib. Nepalese Stud. 1980, 8, $21-40$.

7. Hodges, R. Primitive and Peasant Markets; Blackwell: Oxford, UK, 1988; ISBN 0-631-14464-1.

8. Smith, C.A. Exchange Systems and the Spatial Distribution of Elites: The Organization of Stratification in Agrarian Societies. In Regional Analysis. Volume II; Smith, C.A., Ed.; Academic Press: New York, NY, USA, 1976; pp. 309-374.

9. Minc, L. Monitoring Regional Market Systems in Prehistory: Models, Methods, and Metrics. J. Anthropol. Archaeol. 2006, 25, 82-116. [CrossRef]

10. Nakoinz, O. Models of Centrality. In Landscape Archaeology. Proceedings of the International Conference Held in Berlin, 6th-8th June 2012; Bebermeier, W., Hebenstreit, R., Kaiser, E., Krause, J., Eds.; eTopoi: Berlin, Germany, 2012; pp. 217-223.

11. Loseby, S.T. Marseille: A Late Antique Success Story? JRS 1992, 82, 165-185. [CrossRef]

12. Knitter, D. Central Places and the Environment. Investigations of an Interdependent Relationship. Dissertation; Freie Universität: Berlin, Germany, 2013.

13. Knitter, D.; Blum, H.; Horejs, B.; Nakoinz, O.; Schütt, B.; Meyer, M. Integrated Centrality Analysis: A Diachronic Comparison of Selected Western Anatolian Locations. Quat. Int. 2013, 312, 45-56. [CrossRef]

14. Hesse, M. Cities, Material Flows and the Geography of Spatial Interaction: Urban Places in the System of Chain. Glob. Netw. 2010, 10, 75-91. [CrossRef]

15. Ancient World Mapping Center. "Roads". Available online: http://awmc.unc.edu/wordpress/map-files/ (accessed on 30 June 2018).

16. Malkin, I. A Small Greek World. Networks in the Ancient Mediterranean; Oxford University Press: Oxford, UK, 2011; ISBN 978-0-19-973481-8.

17. Nury, D.; Tréziny, H. Présentation physique de la région marseillaise. In Marseille et ses Alentours. Carte Archéologique de la Gaule 13/3; Rothé, M.-P., Tréziny, H., Eds.; Académie des Inscriptions et Belles-Lettres: Paris, France, 2005; pp. 84-87; ISBN 2-87754-095-2.

18. Sternberg, M.; Tréziny, H. Le terroir marseillais et les ressources naturelles. In Marseille et ses Alentours. Carte Archéologique de la Gaule 13/3; Rothé, M.-P., Tréziny, H., Eds.; Académie des Inscriptions et Belles-Lettres: Paris, France, 2005; pp. 244-251; ISBN 2-87754-095-2.

19. Leveau, P. Leveau, P. Le territoire d'Arles à l'époque romaine. In Arles. Histoire, Territoire et Cultures; Allard, P., Bertrand, R., Heijmans, M., Rouquette, J.-M., Eds.; Actes Sud: Paris, France, 2008; pp. 135-169; ISBN 978-2-7427-5176-1.

20. Hesnard, A. Le port. In Parcours de VILLES. Marseille: 10 ans D'archéologie, 2600 ans D'histoire; Hesnard, A., Moliner, M., Conche, F., Bouiron, M., Eds.; Edisud: Aix-en-Provence, France, 1999; pp. 17-75; ISBN 2-7449-0121-0. 
21. Maurin, M.; Sillano, B. Transformations de la frange littoral de l'âge du Bronze au haut Moyen Âge. In Marseille, du Lacydon au Faubourg Sainte-Catherine (Ve s. av. J.-C.-XVIIIe s.). Les Fouilles de la Place du Général-de-Gaulle; Bouiron, M., Ed.; Maison des Sciences de l'Homme: Paris, France, 2001; pp. 17-42; ISBN 2-7351-0809-0.

22. Euzennat, M. Circonscription de Provence-Côte d'Azur-Corse (région sud). Gallia 1969, 27, 419-463.

23. Mellinand, P.; Moliner, M.; Sillano, B. Topographie urbaine de Marseille romaine: A la lumière des fouilles récentes. In Fréjus Romaine. La ville et son Territoire. Agglomérations de Narbonnaise, des Alpes Maritimes et de Cisalpine à Travers la Recherche Archéologique; Pasqualini, M., Ed.; APDCA: Antibes, France, 2011; pp. 259-268; ISBN 2-904110-50-X.

24. Allinne, C.; Bruneton, H. Arles face au Rhône: La gestion des inondations dans la ville antique. In Arles, Crau, Camargue, Carte archéologique de la Gaule 13/5; Rothé, M.-P., Heijmans, M., Eds.; Académie des inscriptions et belles-lettres: Paris, France, 2008; pp. 147-151; ISBN 978-2-87954-204-1.

25. Mellinand, P.; Sivan, O. Rapport D'opération de Diagnostic Archéologique: Provence-Alpes-Côte d'Azur, Bouches-du-Rhône, Arles, Gare maritime; Inrap Méditerranée: Nîmes, France, 2011.

26. Isoardi, D. Rapport de fouille de sauvetage lieu-dit 5, Place Jean-Baptiste Massillon; Centre Camille Jullian: Aix-en-Provence, France, 2010.

27. Heijmans, M. Arles durant L'antiquité Tardive. De la Duplex Arelas à l'Urbs Genesii; École française de Rome: Rome, Italy, 2004; ISBN 2-7283-0626-5.

28. Vella, C.; Leveau, P.; Provansal, M. Le canal de Marius et les dynamiques littorales du Golfes de Fos. Gallia 1999, 56, 131-139. [CrossRef]

29. Long, L. De la mer au fleuve: Les ports antiques d'Arles. In César. Le Rhône pour Mémoire. Vingt ans de Fouilles Dans le Fleuve à Arles; Long, L., Picard, P., Eds.; Actes Sud: Arles, France, 2009; pp. 30-43; ISBN 978-2-7427-8610-7.

30. Faudot, M. Le pagus Lucretius dans la mosaïque juridique du territorium de la colonie romaine d'Arles. In Autour des Libri Coloniarum: Colonisation et Colonies dans le Monde Romain, Actes du Colloque International, Besançon, France, 16-18 Octobre 2003; Gonzales, A., Guillaumin, J.-Y., Eds.; Presses Universitaires de Franche-Comté: Besançon, France, 2006; pp. 115-122; ISBN 978-2-84867-155-0.

31. Christol, M. Les bienfaits de la paix romaine: Le développement économique et social d'une agglomération tournée vers l'échange. In Arles. Histoire, Territoire et Cultures; Allard, P., Bertrand, R., Heijmans, M., Rouquette, J.-M., Eds.; Actes Sud: Paris, France, 2008; pp. 179-187; ISBN 978-2-7427-5176-1.

32. France, J.; Hesnard, A. Une statio du quarantième des Gaules et les opérations commerciales dans le port romain de Marseille (place Jules-Verne). JRS 1995, 8, 79-93. [CrossRef]

33. Gohier, P. La Céramique d'un Dépotoir Urbain du Haut-Empire à Arles. L'U.S 1051 et 1052 du site «5, Jean-Baptiste Massillon». Master's Thesis, Université de Provence, Aix-en-Provence, France, 2011-2012.

34. Lang-Desvignes, S. Le mobilier céramique antique, étude préliminaire. In Rapport D'opération de Diagnostic Archéologique: Provence-Alpes-Côte d'Azur, Bouches-du-Rhône, Arles, Gare Maritime; Mellinand, P., Sivan, O., Eds.; Inrap Méditerranée: Nîmes, France, 2011; pp. 142-194.

35. Long, L.; Duperron, G. Le mobilier de la fouille de l'épave romaine Arles-Rhône 7. Un navire fluvio-maritime du IIIe siècle de notre ère. In Actes du Congrès d'Arles 2-5 Juin 2011. Contextes de Consommation à Arles: Le point sur les Connaissances Céramiques. Contextes des Villes Portuaires et Fluviales: Commerce, Economie et Société; Société Française D'étude de la Céramique Antique en Gaule: Marseille, France, 2011; pp. 37-56.

36. Long, L.; Duperron, G. Note préliminaire sur l'épave Arles-Rhône 13. Un navire de mer en contexte fluvial, à Arles, au IVe siècle ap. J.-C. Cahiers D'archéologie Subaquatique 2014, 22, 115-143.

37. Long, L.; Duperron, G. Navigation et commerce dans le delta du Rhône: L'épave Arles-Rhône 14 (IIIe s. ap. J.-C.). In Du Rhône aux Pyrénées: Aspects de la vie Matérielle en Gaule Narbonnaise II. Ier s. av. J.-C.-WIe s. ap. J.-C.; Mauné, S., Duperron, G., Eds.; Mergoil: Montagnac, France, 2013; pp. 125-167; ISBN 978-2-35518-036-1.

38. Bonifay, M.; Carre, M.-B.; Rigoir, Y. Fouilles à Marseille. Les Mobiliers (Ier-VIIe s. ap. J.-C.); Errance: Paris, France, 1998; ISBN 2-87772-155-8.

39. Cavaillès-Llopis, M.-T. Céramiques de l'Antiquité tardive à Marseille (corne du port antique, sondages D II 11 et D II 15). Documents d'Archéologie Méridionale 1986, 9, 167-195. [CrossRef]

40. Bonifay, M.; Pelletier, J.-P. Éléments d'évolution des céramiques de l'Antiquité tardive à Marseille d'après les fouilles de La Bourse (1980-1981). RAN 1983, 16, 285-346. [CrossRef] 
41. Bonifay, M. Observations sur les amphores tardives à Marseille d'après les fouilles de la Bourse (1980-1984). RAN 1986, 19, 269-305. [CrossRef]

42. Bonifay, M.; Mukai, T.; Pelletier, J.-P.; Rigoir, Y. Productions artisanales de l'antiquité tardive. In Marseille et ses Alentours. Carte Archéologique de la Gaule 13/3; Rothé, M.-P., Tréziny, H., Eds.; Académie des Inscriptions et Belles-Lettres: Paris, France, 2005; pp. 260-267; ISBN 2-87754-095-2.

43. France, J. Quadragesima Galliarum. L'organisation Douanière des Provinces Alpestres, Gauloises et Germaniques de L'empire Romain: (Ier siècle avant J.-C.-IIIe siècle après J.-C.); École française de Rome: Rome, Italy, 2001; ISBN 2-7283-0605-2.

44. Early, T. An Essay on Political Economies in Prehistory; Habelt-Verlag: Bonn, Germany, 2017; ISBN 978-3-7749-4115-1.

45. Busquet, R.; Pernoud, R. Histoire du Commerce de Marseille, Tome I. L'Antiquité-Le Moyen Age Jusqu'en 1291; Plon: Paris, France, 1949.

46. Jacobs, J. The Economy of Cities; Vintage Books: New York, NY, USA, 1970.

47. Taylor, P. Extraordinary Cities: Early 'City-ness' and the Origins of Agriculture and States. Int. J. Urban Reg. Res. 2012, 36.3, 415-447. [CrossRef]

48. Poux, M. Pinselaufschrift mit Kolonistennamen auf massaliotischer Weinamphore der Frühkaiserzeit (Saint-Laurent-d'Agny). Z. Papyrol. Epigraphik 2014, 192, 257-264.

49. Bonifay, M. Études sur la Céramique Romaine Tardive d'Afrique; Archaeopress: Oxford, UK, 2004; ISBN 1-84171-651-0.

50. Arnaud, P. Les Routes de la Navigation Antique. Itinéraires en Méditerranée; Errance: Paris, France, 2005; ISBN 2-87772-314-3.

51. Horden, P.; Purcell, N. The Corrupting Sea. A Study of Mediterranean History; Blackwell: Oxford, UK, 2000; ISBN 0-631-21890-4.

(C) 2018 by the author. Licensee MDPI, Basel, Switzerland. This article is an open access article distributed under the terms and conditions of the Creative Commons Attribution (CC BY) license (http://creativecommons.org/licenses/by/4.0/). 